\begin{tabular}{c} 
Volume and Issues Obtainable at Center for Sustainability Research and Consultancy \\
Journal of Accounting and Finance in Emerging Economies \\
ISSN: 2519-0318 ISSN (E) 2518-8488 \\
Volume 3: Issue 1 June 2017 \\
CSRᄃ \\
Journal homepage: www.publishing.globalcsrc.org/jafee \\
\hline
\end{tabular}

\title{
Impact of Basel III framework on financial distress: A case study of Pakistan
}

\author{
${ }^{1}$ Irum Saba, ${ }^{2}$ Hafiz Muhammad Waqas Ashraf, ${ }^{3}$ Rehana Kouser \\ ${ }^{1}$ Assistant Professor, IBA Karachi, Pakistan \\ isaba@iba.edu.pk \\ ${ }^{2}$ Department of Commerce, Bahauddin Zakariya University Multan, Pakistan \\ hmwaqasa@gmail.com \\ ${ }^{3}$ Department of Commerce, Bahauddin Zakariya University Multan, Pakistan \\ rehankouser@bzu.edu.pk
}

\section{ARTICLEDETAILS}

\section{History}

Revised format: May 2017

AvailableOnline: June 2017

\section{Keywords}

Financial distress,

Framework

JEL Classification:

G32, G33, G21

\begin{abstract}
Purpose: Liquidity rules phased under the Basel lllshowsthat the new stable funding ratios (NSFR) increase the stability of the funding structure of the financial institution. Using a Pakistani banking data, the relevance of both Structural liquidity and Capital ratios as defined in the Basel 111 is tested in this research. The broad definition of the failure and distress is used to check the status of the banking sector. If the banks fail, then it is denoted by 1 otherwise 0 and the logistic regression is used in the study. Estimate from several versions of the logistic probability model indicates that the likelihood of failure and distress decrease with increase in liquidity holding while capital ratios are not significant. Results support the Basel lll stance that the NSFR has the inverse relation with the bank failure and distress. Comparison between NSFR-10 and NSFR-14 is also done and the analysis shows that the NSFR-14 is more reliable as compared to the NSFR-10. The bank situations whether it lies in the failure and distress condition or in active banks and variables that have an important impact on the stability and failure of the banks are also discussed.
\end{abstract}

(C) 2017 The authors, under a Creative Commons AttributionNonCommercial 4.0

Corresponding author's email address: rehana.kouser@bzu.edu.pk

Recommended citation:Saba, I., Ashraf, H. M. W., Kouser, R., (2017), Impact of Basel III framework on financial distress: A case study of Pakistan. Journal of Accounting and Finance in Emerging Economies, 3(1) 1-20

DOI:https://doi.org/10.26710/jafee.v3i1.198

\section{Introduction}

Financial institution plays an important role in the development of the economy. Financial crisis highlights the deficiencies of the banking industry therefore there is a need to introduce the specific bank model that helps the banks to maintain the stability even during the financial crisis (Saba et al, 2012, 2015Capital and liquidity ratios, both are important for the stability of the banking industry. If these ratios are good, then the chances of the bank failure decrease many folds. Safety and soundness of the banks increase due to well managed capital and liquidity ratios. These two ratios minimize the different types of risk; insolvency risk decreases by the capital ratio and market risk decrease by the liquidity ratio. Appropriately liquid and better-capitalized banks are considered sounder.

Ideally, researchers use micro data to study how banks can respond to Basel III liquidity requirements. According to Basel Committee for Banking Supervision's (BCBS) Quantitative Impact Survey (QIS) in 
2009, only two-third of the 263 banks surveyed were able to calculate the NSFR and the remaining could not calculate the ratio (BCBS, 2010c). Basel III will be fully applied in 2018. Therefore, it is important to do research on this important topic and collect data about the calculation of the NSFR and LCR.

Basel III is a reform plan announced by the BCBS to address vulnerabilities that were exposed to the crisis (BCBS, 2010). LCR and NSFR are the two prickliest elements. Structural change in the Bank risk profile occurs due to the funding risk that are defined by the Net Stables Funding Ratio, it also defines the short-term funding ratio and long-term funding ratios. Banks that do not gather the NSFR need to decrease assets that require stable funds and raise their stable source of funding (King at all, 2013)

NSFR standard of sustainability and long-term stable funding debt crisis and LCR standard for the cash flow crisis, the bank requires maintaining sufficient liquid assets to cover the required 30 days of crisis. Basel capital rules to achieve the liquidity of assets for short-term service contracts in the traditional focus on the rules.

The recent global financial crisis proves the importance of liquidity risk for the stability of the financial sector. The crisis leads to a new financial regulation, Basel III (in response to the open market failure of the BCBS). Basel III introduced a global minimum standard for liquidity, liquidity coverage ratio (LCR) and net stable funding ratio (NSFR). LCR hopes banks will have enough liquid assets to carry on the business in one month. NSFR is based on long term duration. Both LCR and NSFR are coming through the current observation period.

Financial institutions such as banks deal with a lot of risk. In this case, risk management plays crucialrole and help banks maintain adequate capital liquidity. The banks do not forget the limits for the debt. The goal is to ensure that the banks remains trustworthy for customers and government agencies even when the bank is in hot water. During the global economic crisis of 2008, organization has provided an opportunity for reconstruction of the banking business model. Basel Committee on the financial risk and regulatory perspective BCBS (Banking Supervision) reached to an agreement to change regulations for the banking industry. Hence,BCBS is not only just providing the benchmark ratios to the banks but also monitoring the performance of the banks. This committee allows the banks to discuss the issue related to their operations to increase the quality of the banks.

This paper discusses the minimum level of the liquidity ratios (King, 2013; Dietrich et al., 2014; Hong et al., 2014) and examines the effects of the Basel III on bank capital and liquidity ratios that are helpful for decreasing the failure and distress of the Pakistani banks. The relation between the newly established measures of the banks liquidity structure, (NSFR) the Net Stable Funding Ratio and the bank probability of failure and distress is studied in this paper. The research also focusses on the relation between the Net Stable Funding Ratio (NSFR,2010) and probability of failure and distress of the banks and further check the relation between the Net Stable Funding Ratio (NSFR,2014 with the failure and distress of the banks of the Pakistani economy).

\subsection{Basel III capital and liquidity requirement}

The Basel Committee on Banking Supervision provides a forum for regular cooperation on banking supervisory matters. Its objective is to enhance understanding of key supervisory issues and improve the quality of banking supervision worldwide.

BCBS published the first capital agreement in 1988 known as Basel I. The major attention of the Basel agreement was to assist international banks against credit risk. The agreement established minimum percentage requirement of risk weighted asset to the bank total capital (Santos, 2001). The revision of the agreement was done in 1997 to incorporate market risk, such as interest rate and foreign exchange risk in the risk-weighted capital requirement asset account. Basel I after the round of discussions by central 
bankers from all over the world was published again and known as the 1988 Basel Accord and was enforced by law in 1992.

Basel II initially published in June 2004 with the intention to amend international standards to control how much capital banks need to hold to guard against the financial and operational risks faced by the banks. Basel II uses a "three pillars" concept:

(1) Minimum capital requirements (addressing risk)

(2) Supervisory review and

(3) Market discipline.

One of the main criticismon Basel II was that it does not focus on the micro-prudential regulation and the bank level stability. The situation leads to "too big to fail" and gave rise to the incidents occurring due to moral hazard problem in the banking industry (Schwerter, 2011). Ashraf and Godard (2012), mentioned that, investment in the capital market may remove the risk from the banking sector for an investor with the global financial system.

The global financial crisis of 2007-2009exposed the limitation of the existing banking regulatory framework because of the need to re asses the Basel II accord. This re-evaluation of the regulatory framework of the banking industry revealed a serious shortcoming and beginning of a new structure. This new structure is known as Basel III accord. Basel III was developed in response to the financial crisis 2007. Basel III is an international regulatory agreement that introduced a set of reforms designed to improve the regulation, supervision and management within the banking sector. Largely in response to the credit crisis, banks are required to maintain proper leverage ratios (i.e. LCR) and meet certain minimum capital requirements (i.e. NSFR).

For strengthening the capital requirements, the Basel III framework introduces a non-risk weighted ratio, which is designed to integrate the minimum risk of capital requirements to insure the stability of the banks. In the crisis the fund will be retained stable 3\%, based on risk which is used as back up the step listed above. In addition, BCBS (2010) prepared two regulatory measures of liquidity LCR and NSFR. The goal is to ensure that banks have enough liquid assets to face pressure in short term cash and NSFR for the long-term support. (BCBS,2014).

The calculation of the NSFR is the Available Stable Funding (ASF) to the amount of the Required Stable Funding (RSF):

$$
N S F R=\frac{\mathrm{ASF}}{\mathrm{RSF}}
$$

The ASF includes the portion of the capital and liabilities whereas the RSF include the portion of the asset in the off-balance sheet items(BCBS,2014). For example, the NSFR consider the long-term liabilities are more stable as compared to the short-term liabilities and short-term retail deposits are more stable as compared to the wholesale funding.

Banks can easily meet the requirement of the NSFR ratios by increasing the ASF and by decreasing the RSF(King, 2013). These all activities impact on the banks liquidity management function and focus on the holding of the liquid asset specially government securities. Covasand Driscoll (2014) suggested that the Basel III introduce the minimum liquidity requirement for the banks, so the introduction of the minimum liquidity requirement decreases a loan by 3 percent and increase the securities by 6 percent. Banks can meet the requirement of the NSFR by decreasing the illiquid and risky asset and replace with the liquid asset that helps to strengthen the capital ratio.

BCBS introduced the principles for sound liquidity risk management and supervision, which provide guidance on the risk management and supervision of funding liquidity risk. For improving the liquidity framework, the committee develops two standards for funding and liquidity, to ensure that banks have enough high-quality liquid assets (HQLA) to survive in the stress scenario for 30 days. 
The proxy used in the study is LCR the result of the study is consistent with the results of Hong et al, (2014). LCR is basically usedto ensure that a solvent bank survives a short-term liquidity issue but in case of any problem this can help to eliminate the problem.

Capital and liquidity are bothnecessary for the stability of the banks. Banks seek an optimal combination of capital and liquidity for minimizing the banks risk and financial distress.

\section{Literature Review}

A valuable regulatory tool for the safety and soundness of the banks is capital ratio.CAMELS rating used for evaluating the safety and soundness of the banks especially in the US.Different scholars used capital adequacy, asset quality, management quality, earning quality and sensitivity as an interpreter of bank failure. During the saving and loan crisis of 1980s and in early 1990s US financial institution used the same data (Cole \&Gunther, 1995; DeYoung, 2003; Estrella et al., 2000; Wheelock \& Wilson, 2000). In the recent years many financial institutions used the same framework for the analysis of banks during the global financial crisis (Altunbas, Manganelli, \& Marquez-Ibanez, 2015; Cole \& White, 2012; DeYoung \&Torna, 2013).

These studies detect that heavy reliance on short term market funding and aggressive loan growth are the main reasons of bank failure and non-performing loans, low capitalization and low profitability and this shows the risk to the banks. Literature identify that the better capitalized banks perform better during the global financial crisis. Leverage ratio is a good proxy for measuring the capital rather than the risk adjusted capital ratio (Demirgüç-Kunt, Detragiache, and Merrouche (2013)) Beltratti and Stulz (2012). High capital and low capital both situations encourage banks to take more risk so the relationship between capital and risk is nonlinear (Altunbas et al., 2015). Researchers identified a positive relation between capitals and risk (Delis and Staikouras,2011). Latest studies focus on the Basel III capital ratios to decrease the bank failure ratio (Vazquez and Federico,2015). Studies show the relation between structural liquidity and leverage during the global financial crisis of successive failure. Banks that have lower liquidity and higher leverage ratio in the pre-crisis period were expected to fail after the crisis period and the US \& European banks concentrate on these two ratios during the period of 2001 to 2009 . Using the sample of US commercial banks Hong et.al checked the relation between Basel III liquidity risk measure and bank failure over the period of 2001 to 2011. They discovered that the percentage of the bank failure is partially affected by the NSFR and LCR. The literature indicates that the Basel III liquidity and capital ratios are still developing. Based on existing literature, the research is conducted to find that the capital and liquidity ratio decrease the bank failure or not.

\section{Data and Methodology}

\subsection{Data}

This study focusses on the banks, both distress and active banks. Data was collected from the bank's annual reports. The analysis focusses only on those banks with available data to compute variable of interest (the Basel III capital and liquidity ratios). The data was used for the calculation of the Basel III capital and liquidity ratios in terms of balance sheet items and specifically in the form of ratios of the balance sheet. During the data collection process, the following problems were faced (i) Annual reports were not prepared according to BCBS requirements (ii) In annual reports, data was not categorized. All the categories were treated under the one main head. Simply because these requirements were not necessary before the new regulation proposed by the BCBS (2010). Over all, sample includes 30 banks, with the observation 180 years in total. Due to unavailability of the data some bankswere dropped. The final sample comprise is of 21 banks with the 126 observations in total.

The selected sample is of Pakistani banking industry. Annual reports of the banks, reports published by the central bank of Pakistan and interviews of the banking professionals were main source of data collection for the study.banking.Different proxies areused in the study for the capital ratios (ETA, 
TIER1RATIO, TRCR) to check the relation with the different combination of the capital and structure liquidity ratio and capital ratio with the bank failure and distress.

\subsection{Empirical Methodology}

The logistic model is used to check the relation between bank failure and Basel III liquidity and capital measure. Logit models have been extensively used in the literature (Kumar et al., 2003; Kalotychou (2006); Fuertes and Kalotychou, 2007; Davis and Karim, 2008; Poghosyan and Čihak, 2011; LoDuca and Peltonen, 2013; Sarlin and Peltonen, 2013; and Betz et al., 2014). Fuertes, Davis and Karim (2008) discussed the appropriateness of this approach. To check the importance of the different independent variables (NSFR-14, NSFR-10 and LCR) and capital ratios (ETA, TIER1RATIO and CAR) that how these variables impact on the failure and distress of the banks, the logit regression with the combination of different variables is used. The models have the following functions:

\section{Equation \# 01}

$$
\begin{aligned}
F D= & \alpha+\beta_{1} N S F R 14+\beta_{2} E T A+\beta_{3} \text { TIER } 1 R A T I O+\beta_{4} N P L_{-} G L_{t-1}+\beta_{5} C I R_{t-1}+\beta_{6} S I Z E_{t-1}+ \\
& \beta_{7} R O A_{t-1}+\beta_{8} D I V_{t-1}+\beta_{9} H H I_{t=1}
\end{aligned}
$$

In equation 1 the capital ratios, Equity to total asset (ETA) and Tier 1Ratio, one of the structure liquidity ratio NSFR14 and other independent variables, bank specific and macroeconomic variables are used

\section{Equation \# 02}

$$
\begin{aligned}
F D= & \alpha+\beta_{1} N S F R 14+\beta_{2} E T A+\beta_{3} C A R+\beta_{4} N P L_{-} G L_{t-1}+\beta_{5} C I R_{t-1}+\beta_{6} S I Z E_{t-1}+ \\
& \beta_{7} R O A_{t-1}+\beta_{8} D I V_{t-1}+\beta_{9} G D P+\beta_{10} I N F
\end{aligned}
$$

In equation 2 the capital ratios, Equity to total asset (ETA) and CAR, one of the structure liquidity ratio NSFR14 and other independent variables, bank specific and macroeconomic variables are used for the regression.

\section{Equation \# 03}

$$
\begin{aligned}
F D= & \alpha+\beta_{1} N S F R 10+\beta_{2} E T A+\beta_{3} \text { TIER } 1 R A T I O+\beta_{4} N P L_{-} G L_{t-1}+\beta_{5} C I R_{t-1}+\beta_{6} S_{I Z E_{t-1}}+ \\
& \beta_{7} R O A_{t-1}+\beta_{8} D I V_{t-1}+\beta_{9} H H I_{t=1}
\end{aligned}
$$

In equation 3 the capital ratios, Equity to total asset (ETA) and TIER1RATIO, one of the structure liquidity ratio NSFR10 and use other independent variables, bank specific and macroeconomic variables are used for the regression.

\section{Equation \# 04}

$$
\begin{aligned}
F D= & \alpha+\beta_{1} N S F R 10+\beta_{2} E T A+\beta_{3} C A R+\beta_{4} N P L_{-} G L_{t-1}+\beta_{5} C I R_{t-1}+\beta_{6} S_{I Z E_{t-1}}+ \\
& \beta_{7} R O A_{t-1}+\beta_{8} D I V_{t-1}+\beta_{9} G D P+\beta_{10} I N F
\end{aligned}
$$

In equation 4 the capital ratios, Equity to total asset (ETA) and CAR, one of the structure liquidity ratio NSFR14 and other independent variables, bank specific and macroeconomic variables are used for the regression.

\section{Equation \# 05}

$$
\begin{aligned}
F D= & \alpha+\beta_{1} L C R+\beta_{2} E T A+\beta_{3} T I E R 1 R A T I O+\beta_{4} N P L_{-} G L_{t-1}+\beta_{5} C I R_{t-1}+\beta_{6} S_{I Z E_{t-1}+} \\
& \beta_{7} R_{0} A_{t-1}+\beta_{8} D I V_{t-1}+\beta_{9} H H I_{t=1}
\end{aligned}
$$

In equation 5 the capital ratios, Equity to total asset (ETA) and TIER1RATIO, one of the structure liquidity ratio LCR and use other independent variables, bank specific and macroeconomic variables are used.

\section{Equation \# 06}

$$
\begin{aligned}
F D= & \alpha+\beta_{1} L C R+\beta_{2} E T A+\beta_{3} C A R+\beta_{4} N P L_{-} G L_{t-1}+\beta_{5} C I R_{t-1}+\beta_{6} S I Z E_{t-1}+ \\
& \beta_{7} R O A_{t-1}+\beta_{8} D I V_{t-1}+\beta_{9} G D P+\beta_{10} I N F
\end{aligned}
$$


In equation 6 the capital ratios, Equity to total asset (ETA) and CAR, one of the structure liquidity ratio LCR and use other independent variables, bank specific and macroeconomic variables are used for the regression.

Different equations are used to check the relation of the BASEL 111 framework with Failure and Distress of the banks. In this research not only the Basel 111 variables (NSFR, LCR) are used, but also the other determinants of the failure and distress are studied.

\subsection{Identify failure and distress banks}

The identification process starts with the Z-Score as can assign the status to the banks with the help of ZScore. A bank is classified as a failed and distressed (F\&D) if it satisfies the ratio 1.1 or below the ratio. The main ratios are formulated from the banks' annual reports that are publicly published statement andtaken from the state bank of Pakistan. Data is also taken from the official website of the banks, financial institutions and internet. This research work uses the financial data from 2010 to 2015. (R, Pradhan 2014)

The investor takes best snapshot of the corporate financial health from the Z-score. One of the other ratios that are used for the formulation of the bank status either the bank is financially distress or not is Altman $\mathrm{Z}$-score as it is a measure that is used for the probability of the bankruptcy. The Altman Z-score is based on these ratios that are given below:

\subsection{Z score Formula}

$\mathrm{T} 1=($ Current Assets-Current Liabilities $) /$ Total Assets

T2 $=$ Retained Earnings / Total Assets

T3 = Earnings before Interest and Taxes / Total Assets

T4 = Book Value of Equity / Total Liabilities

Z-Score Bankruptcy Model:

$\mathrm{Z}=6.56 \mathrm{~T} 1+3.26 \mathrm{~T} 2+6.72 \mathrm{~T} 3+1.05 \mathrm{~T} 4$

Zones of Discrimination: $\mathrm{Z}<1.1$ - "Distress" Zone, $\mathrm{Z}>1.1$ "Active" Zone

\section{Table 1}

\begin{tabular}{|c|c|c|c|c|c|c|c|c|c|c|c|c|c|c|}
\hline \multirow{3}{*}{$\begin{array}{l}\text { Bank } \\
\text { Name }\end{array}$} & \multicolumn{12}{|c|}{ Years } & \multirow{3}{*}{$\begin{array}{c}\text { No. of } \\
\text { distress } \\
\text { year }\end{array}$} & \multirow{3}{*}{$\begin{array}{c}\text { Total } \\
\text { active } \\
\text { year }\end{array}$} \\
\hline & \multicolumn{2}{|c|}{2010} & \multicolumn{2}{|c|}{2011} & \multicolumn{2}{|c|}{2012} & \multicolumn{2}{|c|}{2013} & \multicolumn{2}{|c|}{2014} & \multicolumn{2}{|c|}{2015} & & \\
\hline & $F \& D$ & Active & $F \& D$ & Active & $F \& D$ & Active & $F \& D$ & Active & $F \& D$ & Active & $F \& D$ & Active & & \\
\hline $\begin{array}{l}\text { Allied } \\
\text { bank } \\
\end{array}$ & 1.000 & & 1.000 & & 1.000 & & 1.000 & & 1.000 & & 1.000 & & 6 & 0 \\
\hline $\begin{array}{l}\text { Bank al } \\
\text { Habib }\end{array}$ & 1.000 & & 1.000 & & 1.000 & & 1.000 & & 1.000 & & 1.000 & & 6 & 0 \\
\hline $\begin{array}{l}\text { Askari } \\
\text { bank }\end{array}$ & 1.000 & & 1.000 & & & 0.000 & 1.000 & & 1.000 & & 1.000 & & 5 & 1 \\
\hline $\begin{array}{l}\text { Bank } \\
\text { Islamic }\end{array}$ & & 0.000 & & 0.000 & & 0.000 & & 0.000 & & 0.000 & & 0.000 & 0 & 6 \\
\hline $\begin{array}{l}\text { bank of } \\
\text { Khyber }\end{array}$ & 1.000 & & 1.000 & & 1.000 & & & 0.000 & & 0.000 & 1.000 & & 4 & 2 \\
\hline $\begin{array}{l}\text { Faysal } \\
\text { bank }\end{array}$ & 1.000 & & 1.000 & & 1.000 & & 1.000 & & 1.000 & & 1.000 & & 6 & 0 \\
\hline $\begin{array}{l}\text { Habib } \\
\text { bank }\end{array}$ & & 0.000 & & 0.000 & & 0.000 & & 0.000 & & 0.000 & & 0.000 & 0 & 6 \\
\hline JS bank & & 0.000 & & 0.000 & & 0.000 & & 0.000 & & 0.000 & 1.000 & & 1 & 5 \\
\hline Meezan & 1.000 & & 1.000 & & 1.000 & & 1.000 & & & 0.000 & & 0.000 & 4 & 2 \\
\hline
\end{tabular}




\begin{tabular}{|c|c|c|c|c|c|c|c|c|c|c|c|c|c|c|}
\hline bank & & & & & & & & & & & & & & \\
\hline NBP & & 0.000 & & 0.000 & & 0.000 & & 0.000 & & 0.000 & & 0.000 & 0 & 6 \\
\hline Smbabank & & 0.000 & & 0.000 & & 0.000 & & 0.000 & & 0.000 & 1.000 & & 1 & 5 \\
\hline $\begin{array}{l}\text { Sindh } \\
\text { bank }\end{array}$ & & 0.000 & & 0.000 & 1.000 & & & 0.000 & & 0.000 & 1.000 & & 2 & 4 \\
\hline $\begin{array}{l}\text { Summit } \\
\text { bank }\end{array}$ & 1.000 & & 1.000 & & 1.000 & & & 0.000 & & 0.000 & 1.000 & & 4 & 2 \\
\hline UBL bank & & 0.000 & & 0.000 & & 0.000 & & 0.000 & & 0.000 & & 0.000 & 0 & 6 \\
\hline ZTBL & & 0.000 & & 0.000 & & 0.000 & & 0.000 & & 0.000 & & 0.000 & 0 & 6 \\
\hline $\begin{array}{l}\text { MCB } \\
\text { bank }\end{array}$ & & 0.000 & & 0.000 & & 0.000 & & 0.000 & 1.000 & & & 0.000 & 1 & 5 \\
\hline $\begin{array}{l}\text { BANK } \\
\text { alflah }\end{array}$ & & 0.000 & & 0.000 & & 0.000 & & 0.000 & 1.000 & & & 0.000 & 1 & 5 \\
\hline BOP & & 0.000 & & 0.000 & 1.000 & & & 0.000 & & 0.000 & & 0.000 & 1 & 5 \\
\hline burj bank & & 0.000 & & 0.000 & 1.000 & & & 0.000 & 1.000 & & & 0.000 & 2 & 4 \\
\hline $\begin{array}{l}\text { soneri } \\
\text { bank }\end{array}$ & 1.000 & & 1.000 & & 1.000 & & 1.000 & & 1.000 & & 1.000 & & 6 & 0 \\
\hline Silk bank & & 0.000 & & 0.000 & & 0.000 & 1.000 & & & 0.000 & & 0.000 & 1 & 5 \\
\hline
\end{tabular}

This table shows the detail of the bank's failure and distress level according to the year. It shows that how many years one bank faced failure and distressed condition. The bank is considered fail and distressed if the value of the bank's Z-score is below 1.1 and the other banks whose values are greater than 1.1 then the bank is considered as an active bank. Last two columns show the details of the banks either they are the active or distressed and how many years one banks suffer the failure and distress.

\subsection{Capital and liquidity indicator}

Basel 111 capital and structure liquidity standards are main target variables. To measure bank capital, different ratios are computed, a non-risk weighted leverage ratio equal to the equity to total asset, and two risk-based measure Tier 1 capital ratios (defined as the ratio of tier 1 capital dividing by the risk weighted asset), and total regulatory capital ratio (defined as the ratio of tier 1 and tier 2 capital to risk weighted asset), denoted by the TIER1RATIO and CAR respectively. These proxies are broadly used in the literature (Betz et al., 2014; Mayes and Stremmel, 2014; Vazquez and Federico, 2015). The relation of these ratios with the $F \& D$ is expected to be negative if these ratios ETA (Equity to total asset), TIER1RATIO and TRCR leads to decrease in the Failure and Distress probability.

For the computation of the structural liquidity ratio, two versions are calculated: NSFR 2014, based on the latest version of the Basel 111 in October 2014, and NSFR 2010, based on the original documents of December 2010 and other important liquidity coverage ratio (LCR). Annual reports of the Pakistani banks do not cover all the information that are required in the Basel 111 documents. The following assumptions are made while computing NSFR

According to the Basel 1llthe loan portfolio of the residual maturity cannot be divided because the Basel 111 require different weights, corporate and retail loans are preserved relatively conservatively ( Gobat et al., 2014), with all these types of loans it is assumed that the loans have maturity of more than 1 year and hence a RSF weight of 85 percent. There is an expected negative relation between the structure liquidity measure and the probability of bank failure and distress, whereby a higher NSFR is associated with lower liquidity risk and hence greater bank stability.

\section{Formula table}




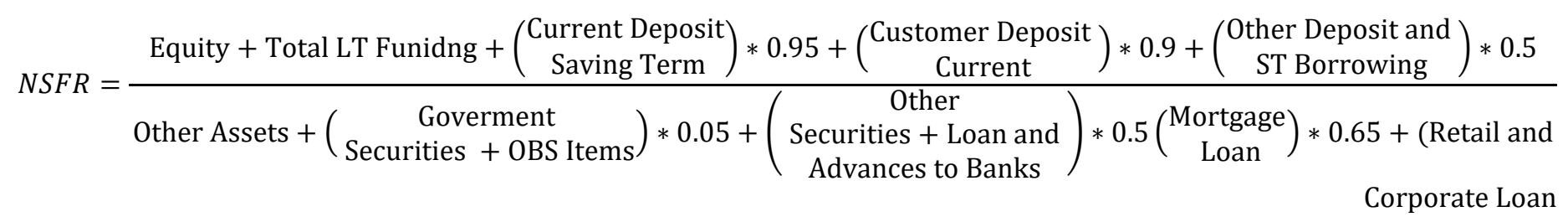




\subsection{Other determinants of bank failure}

Different variables are considered as a predictor of the bank failure. The studies investigating the bank failure used different determinants, one of the most powerful predictor of the bank failure is CAMELS indicators (Betz et al., 2104, Saba et al., 2012, 2015, kouser et al., 2011, 2012, 2016).

. In this paper the non-performing loan to gross loan (NPL-GL) in the place of asset quality is used. This ratio shows the quality of the loan portfolio. If this ratio is high, it means the quality of the bank portfolio is low and the higher ratio of (NPL-GL) increase the chances of the probability bank failure and distress. Next, added another ratio namely cost-to-income ratio use as a proxy of bank operational efficiency. This CIR ratio show the managerial quality of the banks if the ratio is low it indicates the better managerial quality, the expected relation between the CIR and probability of bank failure and distress is positive.

To measure bank earning t the return on average assets (ROAA) is used. The expected relation between the ROAA and banks probability of failure and distress is negative. The higher the ROAA ratio decrease the probability of failure. In addition, a set of control variables to the CAMELS covariates are included in the studyRatio of non-interest income to operating revenue as a proxy for the diversification (DIV) is used and the relationship between DIV and probability of failure and distress is negative. DIV indicates the reduction of the risk and therefore it leads to decrease the failure and distress of the banks.

The natural logarithm of the banks total assets is used as a substitution of the bank size (SIZE). The relation of SIZE and probability of bank failure and distress is uncertain. Because the SIZE of banks effects differently on the failure and distress. The relationship can be negative when the growth of the assets leads to the efficiency gain (scale and scope efficiency), which should lead to higher bank stability.

On the other hand, the relationship between the diversification strategies and the risk exposure is expected to positive and with the volatility of earning (Allen and Jagtiani, 2000) (DeYoung and Roland, 2001; DeJonghe, 2010; Demirguc-Kunt and Huizinga, 2010). In addition to bank specific control, the study focusses on measure of market concentration and macroeconomic variables (Männasoo and Mayes, 2009; Betz et al., 2014). We include the annual inflation rate (INF) and annual percentage change of gross domestic product (GDPC). It is estimated that the high inflation rate and low GDP increase bank vulnerability.

Banking system concentration also effects on the stability of the banks and effects on the failure and distress of the banks. banking system concentration can be assessed Herfindahl-Hirschman index (hereafter HHI). The HHI is considered as the sum of the squared market share value (in term of total assets) of all banks in the country. The hypothetical relationship linking HHI to bank survival is undefined. Certain studies emphasis on bank obligations and forecast a negative relationship between market concentration and banks' risk of failure (see Allen and Gale, 2000, 2004; Carletti, 2008; Beck et al., 2013).

Table \# 2

\begin{tabular}{|c|l|}
\hline Variables & Definition \\
\hline ETA & Equity to total Asset \\
\hline TIER1RATIO & The ratio of tier1 capital to risk weighted assets \\
\hline TRCR & The ratio of tier1 and tier 2 capital to risk weighted assets. \\
\hline NSFR2014 & $\begin{array}{l}\text { The ratio of available stable funding to require stable funding as defined by the new final Basel III } \\
\text { version of October 2014. }\end{array}$ \\
\hline NSFR2010 & $\begin{array}{l}\text { The ratio of available stable funding to require stable funding as defined by the new final Basel III } \\
\text { version of October } 2014 .\end{array}$ \\
\hline \multicolumn{2}{|c|}{ Other determinants of bank failure and distress } \\
\hline ROAA & The ratio of net income to average total assets. \\
\hline CIR & Cost-to-income ratio is calculated by dividing the operating expense by the operating income. \\
\hline NPL_GL & The ratio of non-performing loans to gross loans \\
\hline
\end{tabular}




\begin{tabular}{|c|l|}
\hline DIV & The ratio of non-interest income to net operating revenue. \\
\hline SIZE & The natural logarithm of total assets. \\
\hline GDPC & The annual percentage change of GDP \\
\hline INFC & The annual percentage change of inflation \\
\hline HHI & The sum of the squared market share value (in term of total assets) of all Banks in the country. \\
\hline
\end{tabular}

This table shows the detail of the variables and the definition of the variables. This table also help us to calculate the variables.

\section{Table \# 03 \\ NSFR Calculation}

This table summarizes the weights for each asset and liability items used to compute the last version of the NSFR of October 2014 and the previous version December 2010. NSFR computed as the ratio of (ASF) to (RSF).

\begin{tabular}{|c|c|c|c|}
\hline ASF factor & Bank Scope Liability \& Equity Items & ASF factor & Bank Scope Liability \& Equity Items \\
\hline \multicolumn{2}{|c|}{2014} & \multicolumn{2}{|c|}{2010} \\
\hline \multirow[t]{2}{*}{$100 \%$} & Total equity & $100 \%$ & Total equity \\
\hline & Total long-term funding & & Total long-term funding \\
\hline $95 \%$ & Customer deposits savings and terms & $90 \%$ & Customer deposits savings and terms \\
\hline $90 \%$ & Customer deposits current & $80 \%$ & Customer deposits current \\
\hline $50 \%$ & Other deposits and short-term borrowings & $50 \%$ & Other deposits and short-term borrowings \\
\hline $0 \%$ & Deposits from banks & $0 \%$ & Deposits from banks \\
\hline RSF factor & Bank Scope Asset Items & RSF factor & Bank Scope Asset Items \\
\hline \multicolumn{2}{|c|}{2014} & \multicolumn{2}{|c|}{2010} \\
\hline \multirow[t]{2}{*}{$0 \%$} & Cash and due from banks & $\mathbf{0 \%}$ & Cash and due from banks \\
\hline & & & Loans and advance to banks \\
\hline $5 \%$ & Government Securities & $5 \%$ & Government Securities \\
\hline \multirow[t]{2}{*}{$50 \%$} & Other securities & $50 \%$ & Other securities \\
\hline & Loans and advance to banks & & \\
\hline $65 \%$ & Residential mortgage loans & $65 \%$ & Residential mortgage loans \\
\hline \multirow[t]{6}{*}{$85 \%$} & Net loans & $85 \%$ & Net loans \\
\hline & - residential mortgage loans & & - residential mortgage loans \\
\hline & Reserve for impaired loans/NPLs & & Reserve for impaired loans/NPLs \\
\hline & Non-earning assets (=total assets - total & & Non-earning assets (=total assets - total \\
\hline & earning assets - cash and due from banks) & & earning assets - cash and due from banks) \\
\hline & Fixed assets & & $\begin{array}{l}\text { Fixed assets } \\
\end{array}$ \\
\hline \multirow[t]{4}{*}{$100 \%$} & Other earning assets & $100 \%$ & Other earning assets \\
\hline & Insurance assets & & Insurance assets \\
\hline & Investments in property & & Investments in property \\
\hline & At-equity investments in associates & & At-equity investments in associates \\
\hline $5 \%$ & Off-balance sheet items & $5 \%$ & Off-balance sheet items \\
\hline
\end{tabular}

This table shows the weights of the specific variable that will helpful for the calculation of the NSFR-14 and NSFR-10. In this table clear the difference between the NSFR10 and NSFR-14 according to their weights and calculation. 


\subsection{Descriptive Statistics}

This section describes the descriptive statistics of the variables. The table reports the descriptive statistics of Capital variable for both active and Failure and distress banks. The proxies that are used for the Capital ratios are the (ETA, CAR and TIER1RATIO). All the variables are winsorised by 5 percent. According to the descriptive statistics of the capital variables shows that the mean value of the failure and distress banks of the ETA, CAR and TIER1RATIO are always less as compared to the active banks. The mean value of the capital ratio of the active banks is always higher. We consider the banks failure and distress if the banks Z-Score ratio is less than 1.1. The banks that have the Z-Score value more than 1.1 then it will be consider as an active and efficient bank. All the banks are categorized according to the ratio of the ZScore.

\begin{tabular}{|l|c|r|r|r|r|r|r|r|}
\hline \multicolumn{7}{|c|}{ Table \# 04 } \\
\hline Variables & \multicolumn{7}{|c|}{ F\&D Danks } \\
\hline & Mean & \multicolumn{1}{|c|}{ ST.d } & \multicolumn{1}{|c|}{ Min } & Max & \multicolumn{1}{c|}{ Mean } & \multicolumn{1}{|c|}{ ST.d } & \multicolumn{1}{|c|}{ Min } & Max \\
\hline ETA & 0.0775 & 0.0372912 & 0.048019 & 0.2597636 & 0.120568 & 0.061376 & 0.048019 & 0.259764 \\
\hline CAR & 0.1282 & 0.040774 & 0.05352 & 0.2704954 & 0.214798 & 0.135112 & 0.05352 & 0.526128 \\
\hline TIER1RATIO & 0.1019 & 0.0286306 & 0.046109 & 0.1707572 & 0.19546 & 0.139305 & 0.046109 & 0.524266 \\
\hline
\end{tabular}

Table reports the descriptive statistics of our Structural Liquidity for both active and Failure and distress banks. The proxies that are used for the Structural Liquidity ratios are the (NSFR both version, NSFR14 and NSFR 10). All the variables are winsorised by 5 percent. According to the descriptive statistics of the Liquidity variables shows that the mean value of the failure and distress banks of the NSFR14 and NSFR10 are always less as compared to the active banks. The mean value of the Liquidity ratio of the active banks is always higher. We consider the banks failure and distress if the banks Z-Score ratio is less than 1.1. The banks that have the Z-Score value more than 1.1 then it will be consider as an active and efficient bank. So, we differentiate all the banks according to the ratio of the Z-Score.

\section{Table \# 05}

\begin{tabular}{|l|c|c|c|c|c|c|c|c|}
\hline \multicolumn{9}{|c|}{ Summary statistics of the Liquidity ratios of bank F\&D by bank status } \\
\hline Variables & \multicolumn{3}{|c|}{ F\&D Banks } & \multicolumn{5}{c|}{ Active banks } \\
\hline & Mean & ST.d & Min & Max & Mean & ST.d & Min & Max \\
\hline NSFR14 & 1.8527 & 0.581491 & 1.140491 & 2.930967 & 1.993036 & 0.456115 & 1.140491 & 2.930967 \\
\hline NSFR10 & 1.7506 & 0.5424526 & 1.084636 & 2.796657 & 1.914961 & 0.451773 & 1.084636 & 2.796657 \\
\hline
\end{tabular}

Table reports the descriptive statistics of the other variable for both active and Failure and distress banks. All the variables are winsorised by 5 percent. According to the descriptive statistics of the other variables shows that the mean value of the failure and distress banks of the other variables are always less as compared to the active banks. The mean value of the Liquidity ratio of the active banks is always higher. We consider the banks failure and distress if the banks Z-Score ratio is less than 1.1. The banks that have the Z-Score value more than 1.1 then it will be consider as an active and efficient bank. So, we differentiate all the banks according to the ratio of the Z-Score.

Table \# 06

\begin{tabular}{|l|r|r|r|r|r|r|r|r|}
\hline \multicolumn{7}{|c|}{ Summary Statistics of the other determinants of bank F\&D by bank status } \\
\hline Variables & \multicolumn{3}{|c|}{ F\&D Banks } & \multicolumn{4}{c|}{ Active banks } \\
\hline & \multicolumn{1}{|c|}{ Mean } & \multicolumn{1}{|c|}{ ST.d } & \multicolumn{1}{c|}{ Min } & \multicolumn{1}{c|}{ Max } & \multicolumn{1}{l|}{ Mean } & \multicolumn{1}{l|}{ ST.d } & \multicolumn{1}{l|}{ Min } & Max \\
\hline ROA-1 & 0.006 & 0.0095219 & -0.0138 & 0.0201 & 0.009242 & 0.010105 & -0.0138 & 0.0263 \\
\hline SIZE-1 & 11.486 & 0.3325036 & 10.77733 & 12.19024 & 11.3751 & 0.533141 & 10.54225 & 12.19024 \\
\hline DIV-1 & 0.3171 & 0.1318417 & 0.122138 & 0.591413 & 0.285919 & 0.120761 & 0.107033 & 0.591413 \\
\hline CIR-1 & 0.7001 & 0.1823827 & 0.354364 & 0.9766772 & 0.636651 & 0.174938 & 0.354364 & 0.976677 \\
\hline HHI-1 & 18888 & 61.89044 & 18790.75 & 18971.01 & 18888.26 & 61.36668 & 18790.75 & 18971.01 \\
\hline
\end{tabular}




\begin{tabular}{|l|r|r|r|r|r|r|r|r|}
\hline INF-1 & -0.205 & 0.2159774 & -0.6493 & 0.0170943 & -0.2045 & 0.21415 & -0.6493 & 0.017094 \\
\hline GDP-1 & 0.0366 & 0.0053467 & 0.025805 & 0.0423916 & 0.036599 & 0.005302 & 0.025805 & 0.042392 \\
\hline
\end{tabular}

\section{Table \# 07}

This Table reports the descriptive statistics of the target variable (ETA, TIER1RATIO and CAR) by bank status (Failure \& distress and active banks) and by year. In this table also shows that the average value of the active banks is higher as compared to the failure and distress banks. All the variables are winsorised by 5 percent. We consider the banks failure and distress if the banks Z-Score ratio is less than 1.1 . The banks that have the Z-Score value more than 1.1 then it will be consider as an active and efficient bank. So, we differentiate all the banks according to the ratio of the Z-Score.

\begin{tabular}{|c|c|c|c|c|c|c|c|c|c|c|c|c|c|c|c|c|c|c|}
\hline \multirow{4}{*}{$\begin{array}{l}\text { ye } \\
\text { ar }\end{array}$} & \multicolumn{3}{|c|}{$\begin{array}{c}\text { ACTIVE } \\
\text { BANKS }\end{array}$} & \multirow{2}{*}{\multicolumn{3}{|c|}{$\begin{array}{l}\text { F\&D BANKS } \\
A\end{array}$}} & \multicolumn{3}{|c|}{$\begin{array}{l}\text { ACTIVE } \\
\text { BANKS }\end{array}$} & \multicolumn{3}{|c|}{ F\&D BANKS } & \multicolumn{3}{|c|}{$\begin{array}{l}\text { ACTIVE } \\
\text { BANKS }\end{array}$} & \multicolumn{3}{|c|}{ F\&D BANKS } \\
\hline & \multicolumn{3}{|c|}{ ETA } & & & & \multicolumn{6}{|c|}{ TIER1RATIO } & \multicolumn{6}{|c|}{ CAR } \\
\hline & Mean & \multicolumn{2}{|c|}{$\begin{array}{l}\text { Min- } \\
\text { Max }\end{array}$} & Mean & \multicolumn{2}{|c|}{$\begin{array}{l}\text { Min- } \\
\text { Max }\end{array}$} & Mean & \multicolumn{2}{|c|}{$\begin{array}{l}\text { Min- } \\
\text { Max }\end{array}$} & Mean & \multicolumn{2}{|c|}{$\begin{array}{l}\text { Min- } \\
\text { Max }\end{array}$} & Mean & \multicolumn{2}{|c|}{$\begin{array}{l}\text { Min- } \\
\text { Max }\end{array}$} & Mean & \multicolumn{2}{|c|}{$\begin{array}{l}\text { Min- } \\
\text { Max }\end{array}$} \\
\hline & $\begin{array}{l}\text { (Std. } \\
\text { Dev) }\end{array}$ & & & $\begin{array}{l}\text { (Std. } \\
\text { Dev) }\end{array}$ & & & $\begin{array}{l}\text { (Std. } \\
\text { Dev) }\end{array}$ & & & $\begin{array}{l}\text { (Std. } \\
\text { Dev) }\end{array}$ & & & $\begin{array}{l}\text { (Std. } \\
\text { Dev) }\end{array}$ & & & $\begin{array}{l}\text { (Std. } \\
\text { Dev) }\end{array}$ & & \\
\hline \multirow{2}{*}{$\begin{array}{l}20 \\
10\end{array}$} & 0.135 & $\begin{array}{r}0.0 \\
52\end{array}$ & $\begin{array}{r}0.2 \\
19\end{array}$ & 0.084 & $\begin{array}{r}0.0 \\
52\end{array}$ & $\begin{array}{r}0.1 \\
85\end{array}$ & 0.178 & $\begin{array}{r}0.0 \\
66\end{array}$ & $\begin{array}{r}0.4 \\
33\end{array}$ & 0.103 & $\begin{array}{r}0.0 \\
66\end{array}$ & $\begin{array}{r}0.1 \\
58\end{array}$ & 0.197 & $\begin{array}{r}0.0 \\
78\end{array}$ & $\begin{array}{r}0.4 \\
34\end{array}$ & 0.122 & $\begin{array}{r}0.0 \\
78\end{array}$ & $\begin{array}{r}0.1 \\
66\end{array}$ \\
\hline & 0.060 & & & 0.043 & & & 0.124 & & & 0.031 & & & .117 & & & 0.027 & & \\
\hline \multirow{2}{*}{$\begin{array}{l}20 \\
11\end{array}$} & 0.131 & $\begin{array}{r}0.0 \\
52\end{array}$ & $\begin{array}{r}0.2 \\
19\end{array}$ & 0.083 & $\begin{array}{r}0.0 \\
52\end{array}$ & $\begin{array}{r}0.1 \\
51\end{array}$ & 0.183 & $\begin{array}{r}0.0 \\
66\end{array}$ & $\begin{array}{r}0.4 \\
33\end{array}$ & 0.150 & $\begin{array}{r}0.0 \\
66\end{array}$ & $\begin{array}{r}0.4 \\
33\end{array}$ & 0.197 & $\begin{array}{r}0.0 \\
78\end{array}$ & $\begin{array}{r}0.4 \\
34\end{array}$ & 0.169 & $\begin{array}{r}0.0 \\
78\end{array}$ & $\begin{array}{r}0.4 \\
34\end{array}$ \\
\hline & 0.061 & & & 0.033 & & & 0.122 & & & 0.120 & & & 0.117 & & & 0.113 & & \\
\hline \multirow{2}{*}{$\begin{array}{l}20 \\
12\end{array}$} & 0.117 & $\begin{array}{r}0.0 \\
56\end{array}$ & $\begin{array}{r}0.2 \\
19 \\
\end{array}$ & 0.088 & $\begin{array}{r}0.0 \\
52\end{array}$ & $\begin{array}{r}0.1 \\
43\end{array}$ & 0.167 & $\begin{array}{r}0.0 \\
66\end{array}$ & $\begin{array}{r}0.4 \\
33\end{array}$ & 0.174 & $\begin{array}{r}0.0 \\
66\end{array}$ & $\begin{array}{r}0.4 \\
33\end{array}$ & 0.190 & $\begin{array}{r}0.0 \\
78\end{array}$ & $\begin{array}{r}0.4 \\
34\end{array}$ & 0.188 & $\begin{array}{r}0.0 \\
78\end{array}$ & $\begin{array}{r}0.4 \\
34\end{array}$ \\
\hline & 0.058 & & & 0.033 & & & 0.102 & & & 0.131 & & & 0.097 & & & 0.125 & & \\
\hline \multirow{2}{*}{$\begin{array}{l}20 \\
13\end{array}$} & 0.119 & $\begin{array}{r}0.0 \\
52 \\
\end{array}$ & $\begin{array}{r}0.2 \\
19 \\
\end{array}$ & 0.069 & $\begin{array}{r}0.0 \\
52 \\
\end{array}$ & $\begin{array}{r}0.0 \\
93 \\
\end{array}$ & 0.183 & $\begin{array}{r}0.0 \\
66 \\
\end{array}$ & $\begin{array}{r}0.4 \\
33 \\
\end{array}$ & 0.151 & $\begin{array}{r}0.0 \\
66 \\
\end{array}$ & $\begin{array}{r}0.4 \\
33 \\
\end{array}$ & 0.198 & $\begin{array}{r}0.0 \\
78 \\
\end{array}$ & $\begin{array}{r}0.4 \\
34 \\
\end{array}$ & 0.168 & $\begin{array}{r}0.0 \\
78 \\
\end{array}$ & $\begin{array}{r}0.4 \\
34 \\
\end{array}$ \\
\hline & 0.052 & & & 0.017 & & & 0.117 & & & 0.127 & & & 0.115 & & & 0.122 & & \\
\hline \multirow{2}{*}{$\begin{array}{l}20 \\
14\end{array}$} & 0.109 & $\begin{array}{r}0.0 \\
52\end{array}$ & $\begin{array}{r}0.2 \\
19 \\
\end{array}$ & 0.104 & $\begin{array}{r}0.0 \\
53 \\
\end{array}$ & $\begin{array}{r}0.2 \\
19 \\
\end{array}$ & 0.174 & $\begin{array}{r}0.0 \\
66 \\
\end{array}$ & $\begin{array}{r}0.4 \\
33 \\
\end{array}$ & 0.132 & $\begin{array}{r}0.0 \\
87\end{array}$ & $\begin{array}{r}0.2 \\
05 \\
\end{array}$ & 0.201 & $\begin{array}{r}0.0 \\
78\end{array}$ & $\begin{array}{r}0.4 \\
34\end{array}$ & 0.158 & $\begin{array}{r}0.1 \\
22 \\
\end{array}$ & $\begin{array}{r}0.2 \\
08 \\
\end{array}$ \\
\hline & 0.054 & & & 0.058 & & & 0.125 & & & 0.044 & & & 0.118 & & & 0.038 & & \\
\hline \multirow{2}{*}{$\begin{array}{l}20 \\
15\end{array}$} & 0.098 & $\begin{array}{r}0.0 \\
52\end{array}$ & $\begin{array}{r}0.2 \\
19\end{array}$ & 0.085 & $\begin{array}{r}0.0 \\
52\end{array}$ & $\begin{array}{r}0.1 \\
48\end{array}$ & 0.157 & $\begin{array}{r}0.0 \\
87\end{array}$ & $\begin{array}{r}0.4 \\
33\end{array}$ & 0.168 & $\begin{array}{r}0.0 \\
87\end{array}$ & $\begin{array}{r}0.4 \\
33\end{array}$ & 0.178 & $\begin{array}{r}0.0 \\
9\end{array}$ & $\begin{array}{r}0.4 \\
34\end{array}$ & 0.214 & 0.1 & $\begin{array}{r}0.4 \\
34\end{array}$ \\
\hline & 0.048 & & & 0.030 & & & 0.096 & & & 0.102 & & & 0.090 & & & 0.104 & & \\
\hline
\end{tabular}


Table \# 08

This Table reports the descriptive statistics of the target variable (NSFR14 \& NSFR10) by bank status (Failure \& distress and active banks) and by year. In this table also shows that the average value of the active banks is higher as compared to the failure and distress banks. All the variables are winsorised by 5 percent. We consider the bank failure and distress if the banks Z-Score ratio is less than 1.1 . The banks that have the Z-Score value more than 1.1 then it will be consider as an active and efficient bank. So, we differentiate all the banks, according to the ratio of the Z-Score.

\begin{tabular}{|c|c|c|c|c|c|c|c|c|c|c|c|c|c|c|c|c|c|c|}
\hline \multirow{4}{*}{$\begin{array}{l}\text { ye } \\
\text { ar }\end{array}$} & \multicolumn{3}{|c|}{$\begin{array}{l}\text { ACTIVE } \\
\text { BANKS }\end{array}$} & \multicolumn{3}{|c|}{ F\&D BANKS } & \multicolumn{3}{|c|}{$\begin{array}{l}\text { ACTIVE } \\
\text { BANKS }\end{array}$} & \multicolumn{3}{|c|}{ F\&D BANKS } & \multicolumn{3}{|c|}{$\begin{array}{c}\text { ACTIVE } \\
\text { BANKS }\end{array}$} & \multicolumn{3}{|c|}{ F\&D BANKS } \\
\hline & \multicolumn{6}{|c|}{ NSFR-14 } & \multicolumn{6}{|c|}{ NSFR-10 } & \multicolumn{6}{|c|}{ LCR } \\
\hline & Mean & \multicolumn{2}{|c|}{$\begin{array}{l}\text { Min- } \\
\text { Max }\end{array}$} & Mean & \multicolumn{2}{|c|}{$\begin{array}{l}\text { Min- } \\
\text { Max }\end{array}$} & Mean & \multicolumn{2}{|c|}{$\begin{array}{l}\text { Min- } \\
\text { Max }\end{array}$} & Mean & \multicolumn{2}{|c|}{$\begin{array}{l}\text { Min- } \\
\text { Max }\end{array}$} & Mean & \multicolumn{2}{|c|}{$\begin{array}{l}\text { Min- } \\
\text { Max }\end{array}$} & Mean & \multicolumn{2}{|c|}{$\begin{array}{l}\text { Min- } \\
\text { Max }\end{array}$} \\
\hline & $\begin{array}{l}\text { (Std. } \\
\text { Dev) }\end{array}$ & & & $\begin{array}{l}\text { (Std. } \\
\text { Dev) }\end{array}$ & & & $\begin{array}{l}\text { (Std. } \\
\text { Dev) }\end{array}$ & & & $\begin{array}{l}\text { (Std. } \\
\text { Dev) }\end{array}$ & & & $\begin{array}{l}\text { (Std. } \\
\text { Dev) }\end{array}$ & & & $\begin{array}{l}\text { (Std. } \\
\text { Dev) }\end{array}$ & & \\
\hline \multirow{3}{*}{$\begin{array}{l}20 \\
10\end{array}$} & 1.307 & 0.6 & 1.8 & 0.983 & 0.3 & 1.4 & 1.247 & 0.6 & 1.9 & 0.930 & 0.2 & 1.3 & 0.090 & 0.0 & 0.1 & 0.070 & 0.0 & 0.0 \\
\hline & 5 & 85 & 75 & 9 & 2 & 24 & 6 & 29 & 46 & 9 & 82 & 49 & 1 & 7 & 07 & 9 & 61 & 83 \\
\hline & $\begin{array}{c}0.354 \\
0\end{array}$ & & & $\begin{array}{c}0.340 \\
8\end{array}$ & & & $\begin{array}{c}0.374 \\
0\end{array}$ & & & $\begin{array}{c}0.349 \\
4\end{array}$ & & & $\begin{array}{c}0.011 \\
4\end{array}$ & & & $\begin{array}{c}0.009 \\
1\end{array}$ & & \\
\hline \multirow{3}{*}{$\begin{array}{l}20 \\
11\end{array}$} & 1.321 & 0.7 & 1.9 & 1.143 & 0.5 & 1.5 & 1.220 & 0.6 & 1.8 & 1.059 & 0.5 & 1.4 & 0.105 & 0.0 & 0.1 & 0.097 & 0.0 & 0.1 \\
\hline & 3 & 45 & 66 & 8 & 69 & 19 & 3 & 92 & 28 & 5 & 25 & 05 & 6 & 61 & 57 & 4 & 66 & 39 \\
\hline & $\begin{array}{c}0.319 \\
8\end{array}$ & & & $\begin{array}{c}0.287 \\
1\end{array}$ & & & $\begin{array}{c}0.299 \\
2\end{array}$ & & & $\begin{array}{c}0.265 \\
7\end{array}$ & & & $\begin{array}{c}0.036 \\
1\end{array}$ & & & $\begin{array}{c}0.026 \\
8\end{array}$ & & \\
\hline \multirow{3}{*}{$\begin{array}{l}20 \\
12\end{array}$} & 1.386 & 0.6 & 1.8 & 1.173 & 0.3 & 1.7 & 1.302 & 0.5 & 1.8 & 1.085 & 0.3 & 1.6 & 0.113 & 0.0 & 0.1 & 0.078 & 0.0 & 0.0 \\
\hline & 6 & 4 & 76 & 9 & 86 & 65 & 4 & 85 & 2 & 8 & 14 & 54 & 7 & 69 & 57 & 4 & 62 & 98 \\
\hline & $\begin{array}{c}0.395 \\
9\end{array}$ & & & $\begin{array}{c}0.499 \\
6 \\
\end{array}$ & & & $\begin{array}{c}0.380 \\
8 \\
\end{array}$ & & & $\begin{array}{c}0.484 \\
1\end{array}$ & & & $\begin{array}{c}0.029 \\
4\end{array}$ & & & $\begin{array}{c}0.013 \\
0 \\
\end{array}$ & & \\
\hline \multirow{2}{*}{$\begin{array}{l}20 \\
13\end{array}$} & $\begin{array}{c}1.393 \\
5\end{array}$ & $\begin{array}{l}0.9 \\
47\end{array}$ & $\begin{array}{l}1.7 \\
77\end{array}$ & $\begin{array}{c}1.167 \\
0\end{array}$ & $\begin{array}{c}0.5 \\
4\end{array}$ & $\begin{array}{l}1.6 \\
07\end{array}$ & $\begin{array}{c}1.353 \\
1\end{array}$ & $\begin{array}{l}0.9 \\
01\end{array}$ & $\begin{array}{l}1.9 \\
91\end{array}$ & $\begin{array}{c}1.049 \\
4\end{array}$ & $\begin{array}{l}0.4 \\
32\end{array}$ & $\begin{array}{l}1.4 \\
76\end{array}$ & $\begin{array}{c}0.102 \\
1\end{array}$ & $\begin{array}{l}0.0 \\
61\end{array}$ & $\begin{array}{c}0.1 \\
57\end{array}$ & $\begin{array}{c}0.091 \\
0\end{array}$ & $\begin{array}{l}0.0 \\
61\end{array}$ & $\begin{array}{l}0.1 \\
29\end{array}$ \\
\hline & $\begin{array}{c}0.298 \\
7\end{array}$ & & & $\begin{array}{c}0.379 \\
4\end{array}$ & & & $\begin{array}{c}0.337 \\
5\end{array}$ & & & $\begin{array}{c}0.363 \\
3 \\
\end{array}$ & & & $\begin{array}{c}0.035 \\
5\end{array}$ & & & $\begin{array}{c}0.021 \\
1\end{array}$ & & \\
\hline \multirow{3}{*}{$\begin{array}{l}20 \\
14\end{array}$} & 1.426 & 0.6 & 1.9 & 1.392 & 0.3 & 1.9 & 1.342 & 0.5 & 1.8 & 1.309 & 0.3 & 1.8 & 0.099 & 0.0 & 0.1 & 0.092 & 0.0 & 0.1 \\
\hline & 0 & 42 & 33 & 9 & 12 & & 1 & 9 & 09 & 9 & 09 & 45 & 2 & 61 & 57 & 5 & 64 & 16 \\
\hline & $\begin{array}{c}0.3 \mathrm{k} 2 \\
155 \\
\end{array}$ & & & $\begin{array}{c}0.565 \\
4 \\
\end{array}$ & & & $\begin{array}{c}0.299 \\
9 \\
\end{array}$ & & & $\begin{array}{c}0.530 \\
1\end{array}$ & & & $\begin{array}{c}0.030 \\
7 \\
\end{array}$ & & & $\begin{array}{c}0.018 \\
2 \\
\end{array}$ & & \\
\hline \multirow{3}{*}{$\begin{array}{l}20 \\
15\end{array}$} & 1.305 & 0.7 & 1.7 & 1.520 & 1.2 & 1.9 & 1.218 & 0.6 & 1.6 & 1.420 & 1.1 & 1.8 & 0.087 & 0.0 & 0.1 & 0.078 & 0.0 & 0.0 \\
\hline & 5 & 3 & 6 & 5 & 21 & 52 & 5 & 6 & 5 & 4 & 16 & 76 & 2 & 68 & 57 & 1 & 61 & 97 \\
\hline & $\begin{array}{c}0.316 \\
0\end{array}$ & & & $\begin{array}{c}0.282 \\
3\end{array}$ & & & $\begin{array}{c}0.301 \\
3 \\
\end{array}$ & & & $\begin{array}{c}0.286 \\
1\end{array}$ & & & $\begin{array}{c}0.025 \\
2 \\
\end{array}$ & & & $\begin{array}{c}0.011 \\
1\end{array}$ & & \\
\hline
\end{tabular}


Table reports the descriptive statistics of the our all variable for both active and Failure and distress banks. All the variables are winsorised by 5 percent. According to the descriptive statistics of the variables shows that the average value of the failure and distress banks of the other variables are always less as compared to the active banks. The mean value of the variable of the active banks is always higher. We consider the bank failure and distress if the banks Z-Score ratio is less than 1.1. The banks that have the Z-Score value more than 1.1 then it will be considered as an active and efficient bank. So, we differentiate all the banks, according to the ratio of the Z-Score.

Table \# 09

\begin{tabular}{|c|c|c|c|c|}
\hline \multirow{3}{*}{ Variables } & \multicolumn{4}{|c|}{ Summary statistics full sample of the bank } \\
\hline & \multicolumn{4}{|c|}{$\begin{array}{rc}\text { Full Sample } \\
\end{array}$} \\
\hline & Mean & ST.d & Min & Max \\
\hline ETA & 0.1082632 & 0.058763 & 0.0480185 & 0.2597636 \\
\hline TIER1RATIO & 0.1687345 & 0.1258825 & 0.046109 & 0.5242656 \\
\hline CAR & 0.1900586 & 0.1224972 & 0.0535196 & 0.5261277 \\
\hline NSFR14 & 1.952944 & 0.4968423 & 1.140491 & 2.930967 \\
\hline NSFR10 & 1.86799 & 0.4829801 & 1.084636 & 2.796657 \\
\hline LCR & 0.0934981 & 0.026766 & 0.061304 & 0.1566313 \\
\hline ROA-1 & 0.0083238 & 0.0100107 & -0.0138 & 0.0263 \\
\hline Size-1 & 11.40683 & 0.485666 & 10.54225 & 12.19024 \\
\hline DIV-1 & 0.2948256 & 0.1242988 & 0.1070327 & 0.591413 \\
\hline Cir-1 & 0.6547783 & 0.1786939 & 0.3543644 & 0.9766772 \\
\hline Hhi-1 & 18888.26 & 61.26841 & 18790.75 & 18971.01 \\
\hline Inflation-1 & -0.2045012 & 0.2138067 & -0.6492968 & 0.0170943 \\
\hline Gdp-1 & 0.0365994 & 0.005293 & 0.0258051 & 0.0423916 \\
\hline
\end{tabular}

\subsection{Correlation}

Table \# 10

\begin{tabular}{|l|r|r|r|r|r|r|r|r|r|r|r|r|c|}
\hline & ETA & TIER1 & CAR & NSFR14 & NSFR10 & ROA & SIZE & DIV & CIR & HHI & INF & GDP & LCR \\
\hline ETA & 1 & & & & & & & & & & & & \\
\hline $\begin{array}{l}\text { TIER1R } \\
\text { ATIO }\end{array}$ & 0.52 & 1.00 & & & & & & & & & & & \\
\hline CAR & 0.50 & 0.98 & 1.00 & & & & & & & & & & \\
\hline NSFR14 & -0.03 & 0.01 & 0.02 & 1.00 & & & & & & & & & \\
\hline NSFR10 & 0.01 & 0.03 & 0.04 & 0.98 & 1.00 & & & & & & & & \\
\hline ROA & 0.09 & 0.02 & 0.08 & 0.39 & 0.42 & 1.00 & & & & & & & \\
\hline SIZE & -0.49 & -0.40 & -0.32 & 0.26 & 0.26 & 0.52 & 1.00 & & & & & & \\
\hline DIV & -0.23 & -0.36 & -0.35 & -0.17 & -0.17 & -0.18 & 0.07 & 1.00 & & & & & \\
\hline CIR & -0.08 & 0.08 & 0.04 & -0.27 & -0.31 & -0.51 & -0.40 & 0.05 & 1.00 & & & & \\
\hline HHI & 0.12 & -0.01 & -0.06 & -0.27 & -0.29 & -0.05 & -0.26 & -0.05 & 0.06 & 1.00 & & & \\
\hline INF & 0.14 & -0.02 & -0.06 & -0.22 & -0.23 & -0.04 & -0.21 & -0.05 & 0.07 & 0.75 & 1.00 & & \\
\hline GDP & -0.11 & 0.04 & 0.07 & 0.23 & 0.26 & 0.10 & 0.22 & -0.03 & -0.05 & -0.84 & -0.66 & 1.00 & \\
\hline LCR & 0.16 & -0.06 & -0.01 & 0.05 & 0.03 & 0.29 & 0.29 & 0.00 & -0.04 & 0.26 & 0.15 & -0.22 & 1.00 \\
\hline
\end{tabular}

This table shows the result of the correlation matrix for our variables of interest (Capital and Liquidity ratios) and the other explanatory variables. There are many variables that have the pairwise correlation coefficient is statistically significant. Some of the variables has the multicollinearity so we run regression separate from those variables that have the multicollinearity. The magnitude of the correlation is low. 


\subsection{Result}

In this research, the dependent variableis the dummy variable and logistic regression is used. We run the logit regression for the period of the 2010-2015. Due to multicollinearity we run different logistic regression and to find that which combination of the variable are best suitable for the stability of the banks. For example, we run the regression with the different independent variable version (NSFR14 \& NSFR10) to check whether the NSFR 14 is better explained as compare to the NSFR10

\begin{tabular}{|c|c|c|c|c|}
\hline \multicolumn{5}{|c|}{ Table \# 11 } \\
\hline Variable & Coefficient & Std. Error & z-Statistic & Prob. \\
\hline NSFR14 & -0.931828 & 0.558769 & -1.667643 & 0.0954 \\
\hline TIER1RATIO & -7.314482 & 8.310542 & -0.880145 & 0.3788 \\
\hline NPLGL-1 & -7.908628 & 4.151151 & -1.905165 & 0.0568 \\
\hline CIR-1 & 1.420907 & 1.417719 & 1.002249 & 0.3162 \\
\hline SIZE-1 & -0.327107 & 0.613390 & -0.533278 & 0.5938 \\
\hline DIV-1 & 0.975108 & 2.352845 & 0.414438 & 0.6786 \\
\hline HHI-1 & $5.80 \mathrm{E}-05$ & 0.003302 & 0.017564 & 0.9860 \\
\hline ROA-1 & -5.799769 & 31.68397 & -0.183051 & 0.8548 \\
\hline ETA & -12.87970 & 4.787060 & -2.690524 & 0.0071 \\
\hline C & 3.546427 & 64.37960 & 0.055086 & 0.9561 \\
\hline
\end{tabular}

This table shows the result of the equation 01 in this equation the relation between our main target variable (NSFR14) and dependent variable (failure and distress) is negative. It means when the value of the NSFR increase then the probability of bank failure and distress will decrease, and the result are also significant. The relation between the failure and distress with the other independent variable are positive as well as the negative. Some variables have the negative relation with the dependent variable (F\&D). Equity to total asset (ETA),TIER1RATIO, SIZE, ROA and NPL_GL have negative relation with the Failure and Distress. The value of these variables increases the probability of bank failure and distress will decrease. The other remaining variable has the positive relation with the bank failure and distress.

\begin{tabular}{|c|r|r|r|r|}
\hline \multicolumn{5}{|c|}{ Table \# 12 } \\
\hline Variable & Coefficient & Std. Error & z-Statistic & Prob. \\
\hline NSFR14 & -0.936935 & 0.560722 & -1.670942 & 0.0947 \\
\hline GDP-1 & 5.971241 & 53.19839 & 0.112245 & 0.9106 \\
\hline INFLATION-1 & -0.320031 & 1.205798 & -0.265410 & 0.7907 \\
\hline CIR-1 & 1.205155 & 1.306239 & 0.922615 & 0.3562 \\
\hline DIV-1 & 1.054569 & 2.282231 & 0.462078 & 0.6440 \\
\hline NPLGL-1 & -5.226842 & 4.341065 & -1.204046 & 0.2286 \\
\hline CAR & 0.731003 & 2.557082 & 0.285874 & 0.7750 \\
\hline SIZE-1 & -0.312582 & 0.505378 & -0.618512 & 0.5362 \\
\hline ETA & -13.89541 & 5.507982 & -2.522776 & 0.0116 \\
\hline ROA-1 & -4.357626 & 30.36809 & -0.143494 & 0.8859 \\
\hline C & 1.284275 & 2.066897 & 0.621354 & 0.5344 \\
\hline & $\mathrm{R}^{2}$ & & \\
\hline
\end{tabular}

This table shows the result of the equation 02 in this equation the relation between our main target variable (NSFR14) and dependent variable (failure and distress) is negative. It means when the value of the NSFR increase then the probability of bank failure and distress will decrease, and the result are also significant . The relation between the failure and distress with the other independent variable are positive 
as well as the negative. Some variables have the negative relation with the dependent variable (F\&D). Equity to total asset (ETA),TIER1RATIO, SIZE, ROA and NPL_GL have negative relation with the Failure and Distress. The value of these variables increases the probability of bank failure and distress will decrease. The other remaining variable has the positive relation with the bank failure and distress.

\begin{tabular}{|c|c|c|c|c|}
\hline \multicolumn{5}{|c|}{ Table \# 13 } \\
\hline Variable & Coefficient & Std. Error & z-Statistic & Prob. \\
\hline NSFR10 & -0.968212 & 0.571902 & -1.692967 & 0.0905 \\
\hline ETA & -13.56505 & 5.566633 & -2.436850 & 0.0148 \\
\hline GDP-1 & 4.927823 & 65.37302 & 0.075380 & 0.9399 \\
\hline INFLATION-1 & -0.336637 & 1.405577 & -0.239501 & 0.8107 \\
\hline CIR-1 & 1.174806 & 1.309324 & 0.897261 & 0.3696 \\
\hline DIV-1 & 1.073025 & 2.314007 & 0.463709 & 0.6429 \\
\hline ROA-1 & 6.041435 & 34.17366 & 0.176786 & 0.8597 \\
\hline SIZE-1 & -0.425016 & 0.751988 & -0.565189 & 0.5719 \\
\hline NPLGL-1 & -5.278053 & 4.259141 & -1.239229 & 0.2153 \\
\hline TIER1RATIO & 0.607946 & 2.482384 & 0.244904 & 0.8065 \\
\hline C & 1.161977 & 77.42945 & 0.015007 & 0.9880 \\
\hline \multicolumn{2}{|c|}{0.146356} & \\
\end{tabular}

This table shows the result of the equation 03 in this equation the relation between our main target variable (NSFR10) and dependent variable (failure and distress) is negative. It means when the value of the NSFR increase then the probability of bank failure and distress will decrease, and the result are also significant. The relation between the failure and distress with the other independent variable are positive as well as the negative. Some variables have the negative relation with the dependent variable (F\&D). Equity to total asset (ETA),TIER1RATIO, SIZE, ROA and NPL_GL have negative relation with the Failure and Distress. The value of these variables increases the probability of bank failure and distress will decrease. The other remaining variable has the positive relation with the bank failure and distress.

\begin{tabular}{|c|c|c|c|c|}
\hline \multicolumn{5}{|c|}{ Table \# 14 } \\
\hline Variable & Coefficient & Std. Error & z-Statistic & Prob. \\
\hline NSFR10 & -0.939774 & 0.558718 & -1.682021 & 0.0926 \\
\hline ETA & -14.00486 & 5.461270 & -2.564396 & 0.0103 \\
\hline CAR & 0.901253 & 2.552318 & 0.353112 & 0.7240 \\
\hline HHI-1 & $-1.74 \mathrm{E}-06$ & 0.003322 & -0.000524 & 0.9996 \\
\hline ROA-1 & -3.985586 & 31.43058 & -0.126806 & 0.8991 \\
\hline SIZE-1 & -0.274759 & 0.586934 & -0.468126 & 0.6397 \\
\hline CIR-1 & 1.193727 & 1.297582 & 0.919962 & 0.3576 \\
\hline DIV-1 & 1.002895 & 2.276412 & 0.440559 & 0.6595 \\
\hline NPLGL-1 & -5.199571 & 4.294914 & -1.210634 & 0.2260 \\
\hline C & 1.532056 & 62.69899 & 0.024435 & 0.9805 \\
\hline
\end{tabular}

$\mathrm{R}^{2} \quad 0.144817$

This table shows the result of the equation 04 in this equation the relation between our main target variable (NSFR10) and dependent variable (failure and distress) is negative. It means when the value of the NSFR increase then the probability of bank failure and distress will decrease, and the result are also significant. The relation between the failure and distress with the other independent variable are positive as well as the negative. Some variables have the negative relation with the dependent variable (F\&D). Equity to total asset (ETA),TIER1RATIO, SIZE, ROA and NPL_GL have negative relation with the 
Failure and Distress. The value of these variables increases the probability of bank failure and distress will decrease. The other remaining variable has the positive relation with the bank failure and distress.

Table \# 15

\begin{tabular}{|c|c|c|c|c|}
\hline Variable & Coefficient & Std. Error & z-Statistic & Prob. \\
\hline LCR & -22.71415 & 11.22822 & -2.022951 & 0.0431 \\
\hline ETA & -15.37601 & 6.197637 & -2.480948 & 0.0131 \\
\hline TIER1RATIO & -0.227287 & 2.515377 & -0.090359 & 0.9280 \\
\hline GDP-1 & 14.55497 & 55.06428 & 0.264327 & 0.7915 \\
\hline INFLATION-1 & 0.329672 & 1.284395 & 0.256675 & 0.7974 \\
\hline CIR-1 & 0.970828 & 1.640355 & 0.591840 & 0.5540 \\
\hline DIV-1 & 0.200833 & 2.335936 & 0.085976 & 0.9315 \\
\hline NPLGL-1 & -2.852812 & 4.482579 & -0.636422 & 0.5245 \\
\hline ROA-1 & 7.804629 & 34.24753 & 0.227889 & 0.8197 \\
\hline SIZE-1 & -0.461073 & 0.758779 & -0.607651 & 0.5434 \\
\hline C & 7.565057 & 9.323747 & 0.811375 & 0.4172 \\
\hline
\end{tabular}

$\mathrm{R}^{2} \quad 0.145054$

This table shows the result of the equation 05 in this equation the relation between our main target variable (LCR) and dependent variable (failure and distress) is negative. It means when the value of the LCR increase then the probability of bank failure and distress will decrease, and the result are also significant. The relation between the failure and distress with the other independent variable are positive as well as the negative. Some variables have the negative relation with the dependent variable (F\&D). Equity to total asset (ETA),TIER1RATIO, SIZE, ROA and NPL_GL have negative relation with the Failure and Distress. The value of these variables increases the probability of bank failure and distress will decrease. The other remaining variable has the positive relation with the bank failure and distress.

Table \# 16

\begin{tabular}{|c|c|c|c|c|}
\hline Variable & Coefficient & Std. Error & z-Statistic & Prob. \\
\hline LCR & -24.52157 & 11.60674 & -2.112700 & 0.0346 \\
\hline ETA & -15.46547 & 6.286931 & -2.459939 & 0.0139 \\
\hline CIR-1 & 0.973561 & 1.642346 & 0.592787 & 0.5533 \\
\hline DIV-1 & 0.421860 & 2.327933 & 0.181217 & 0.8562 \\
\hline NPLGL-1 & -2.924110 & 4.601039 & -0.635533 & 0.5251 \\
\hline ROA-1 & 3.482840 & 34.10437 & 0.102123 & 0.9187 \\
\hline SIZE-1 & -0.279990 & 0.805269 & -0.347698 & 0.7281 \\
\hline CAR & 0.575452 & 2.572291 & 0.223712 & 0.8230 \\
\hline HHI-1 & 0.002224 & 0.003837 & 0.579643 & 0.5622 \\
\hline C & -36.02922 & 76.39003 & -0.471648 & 0.6372 \\
\hline
\end{tabular}

$\mathrm{R}^{2} \quad 0.146591$

This table shows the result of the equation 06 in this equation the relation between our main target variable (LCR) and dependent variable (failure and distress) is negative. It means when the value of the LCR increase then the probability of bank failure and distress will decrease, and the result are also significant. The relation between the failure and distress with the other independent variable are positive as well as the negative. Some variables have the negative relation with the dependent variable (F\&D). Equity to total asset (ETA),TIER1RATIO, SIZE, ROA and NPL_GL have negative relation with the Failure and Distress. The value of these variables increases the probability of bank failure and distress will decrease. The other remaining variable has the positive relation with the bank failure and distress. In this analysis, we take lagged all the other independent variables. Lagged is used for checking the 
impact of the previous year on the current year. There is autocorrelation exist in this data, so we used lagged values to eliminate the Autocorrelation.

\subsection{Regression Result \& Discussion}

All the above tables show the result of the logistic regression. We run the models on the main variables and other determinants of the bank failure and distress variables. In all the model we use the dummy variable as a dependent variable. In our result, among the main target variable only the NSFR and the LCR is significant determinants of bank failure and distress. The results of the study are in line with the earlier studies(Laura, 2016), (King 2013), (Huiliar, 2014).

Our result confirms the hypothesis. There is negative relation between the NSFR and the Failure and Distress of the banks. The negative relation explains that higher the value of the NSFR will lead to lower the probability of bank failure and distress. Hong et al. (2014) find that the impact of the NSFR on the European banking industry is limited but my result tells that there is highly significant relation with the NSFR and the probability of bank failure and distress.

The result of the capital variables (ETA, TIER1RATIO and CAR) are not significant. And there are many researches that show the result that the capital ratios are never significant (Laura,2016).

The results of the study show that liquidity and capital ratios do not play an important role in the stability of the banks. The research found that the banking industry not only focus on the stability by the capital and liquidity ratios, but the other activities also have an impact on the stability of the banks. To be more exact there is an inverse relation between the Diversification and the bank failure and distress. Other variables (NPL-GL, SIZE and ROA) also inversely related to the probability of bank failure and distress. But the ROA and CIR are not significant in our result. The macroeconomic variables (GDP and INF) also determinants of the bank failure and distress. GDP growth leads to the decrease the inflation and improve the economic condition of the country that leads to decrease the probability of bank failure and distress.

Additionally, the relation of the market concentration on the failure and distress of the banks is also studied. Table 14 shows that there is negative relationship between market concentration and probability of bank failure and distress. It means that the banks which has a more market concentration has less probability of failure and distress. The result become positive when the macroeconomic variables were added in the regression analysis.

\section{Conclusion}

The banking industry is the backbone of the economy of any country. Failure of the banks has a very negative impact on the economy. The global financial crisis $2007-2009$ highlighted the reasons of the failure of the banks. The main reason of the failure of the banks is the risk of maturity mismatch and unstable funding mix on the banks' balance sheet. Which reveals that there is a need to change supervisory and regulatory framework for governing the bank liquidity. The Basel lll reduce the bank failure and promote the stability of banks by using the joint role of structural liquidity and capital ratios.

According to results of the study the requirement of the BCBS is satisfied with the Net Stable Funding Ratio. It is found that the capital and liquidity ratios play important role in the stability of banks and reduce the failure and distress of the banks. Our result also indicates that the banks that have the lower structural liquidity ratios and capital ratios, these banks faces difficulties. Analysis result is valuable particularly in the present debate on the effects of interest to academics and decision-makers that the Bank of Basel III capital structure and liquidity cushion to enhance stability. 


\section{Reference}

Acharya, V. V., \& Mora, N. (2015).A crisis of banks as liquidity providers. The journal of Finance, 70(1), 143.

Ashraf, D., \& Goddard, J. (2012). Derivatives in the wake of disintermediation: a simultaneous equations model of commercial and industrial lending and the use of derivatives by US banks. International Journal of Banking, Accounting and Finance, 4(3), 250-271.

Athanasoglou, P. P., Brissimis, S. N., \& Delis, M. D. (2008).Bank-specific, industry-specific and macroeconomic determinants of bank profitability.Journal of international financial Markets, Institutions and Money, 18(2), 121-136.

Barth, J. R., Caprio, G., \& Levine, R. (2004). Bank regulation and supervision: what works best? Journal of Financial intermediation, 13(2), 205-248.

Beck, T., Demirgüç-Kunt, A., \&Merrouche, O. (2013). Islamic vs. conventional banking: Business model, efficiency and stability. Journal of Banking \& Finance, 37(2), 433-447.

Beltratti, A., \&Stulz, R. M. (2012). The credit crisis around the globe: Why did some banks perform better? Journal of Financial Economics, 105(1), 1-17.

Berger, A. N., \&Bouwman, C. H. (2009).Bank liquidity creation.Review of Financial Studies, 22(9), 37793837.

Bourke, P. (1989). Concentration and other determinants of bank profitability in Europe, North America and Australia.Journal of Banking \& Finance, 13(1), 65-79.

Bourke, P. (1989). Concentration and other determinants of bank profitability in Europe, North America and Australia.Journal of Banking \& Finance, 13(1), 65-79.

Castiglionesi, F., \& Wagner, W. (2009). The optimality of interbank liquidity insurance.

Chiaramonte, L., \&Casu, B. (2016). Capital and liquidity ratios and financial distress. Evidence from the European banking industry. The British Accounting Review.

Chuanwei, X. P. Z. (2010). Post-crisis Financial Regulatory Reform Proposals: A Theoretical Survey. Journal of Financial Research, 2, 003.

Cole, R. A., \& Gunther, J. W. (1995).Separating the likelihood and timing of bank failure.Journal of Banking \& Finance, 19(6), 1073-1089.

Demirgüç-Kunt, A., \& Huizinga, H. (2000).Financial structure and bank profitability.

Demirgüç-Kunt, A., \& Huizinga, H. (2009). Bank activity and funding strategies: The impact on risk and return.

Demirgüç-Kunt, A., \& Huizinga, H. (2009). Bank activity and funding strategies: The impact on risk and return.

DeYoung, R., \&Torna, G. (2013). Nontraditional banking activities and bank failures during the financial crisis.Journal of Financial Intermediation, 22(3), 397-421.

Diamond, D. W., \&Rajan, R. G. (2000).A theory of bank capital.The Journal of Finance, 55(6), 2431-2465.

Diamond, D. W., \&Rajan, R. G. (2001). Liquidity risk, liquidity creation, and financial fragility: A theory of banking. Journal of political Economy, 109(2), 287-327.

Estrella, A., Park, S., \&Peristiani, S. (2000). Capital ratios as predictors of bank failure. Federal reserve bank of New York economic policy review, 6(2), 33.

Gatev, E., \& Strahan, P. E. (2006). Banks' advantage in hedging liquidity risk: Theory and evidence from the commercial paper market. The Journal of Finance, 61(2), 867-892.

Gatev, E., Schuermann, T., \& Strahan, P. (2007). How do banks manage liquidity risk? Evidence from the equity and deposit markets in the Fall of 1998. In The risks of financial institutions (pp. 105132).University of Chicago Press.

Goddard, J., Molyneux, P., \& Wilson, J. O. (2004). The profitability of European banks: a cross-sectional and dynamic panel analysis. The Manchester School, 72(3), 363-381.

Goodhart, C. (2011). The Basel Committee on Banking Supervision: a history of the early years 19741997. Cambridge University Press.

Haldane, A. (2013). Constraining discretion in bank regulation. 
Huang, R., \&Ratnovski, L. (2009).Why are Canadian banks more resilient? (No. 9-152). International Monetary Fund.

Kashyap, A. K., Rajan, R., \& Stein, J. C. (2002). Banks as liquidity providers: An explanation for the coexistence of lending and deposit-taking. The Journal of Finance, 57(1), 33-73.

Kiessling, C., Dieterich, A., Fabry, G., Hölzer, H., Langewitz, W., Mühlinghaus, I., ...\& behalf of the Committee, O. (2010). Communication and social competencies in medical education in Germanspeaking countries: The Basel Consensus Statement.: Results of a Delphi Survey. Patient Education and Counseling, 81(2), 259-266.

King, M. R. (2013). The Basel III net stable funding ratio and bank net interest margins. Journal of Banking \& Finance, 37(11), 4144-4156.

Laeven, L., \& Levine, R. (2009).Bank governance, regulation and risk taking.Journal of Financial Economics, 93(2), 259-275.

Mehran, H., Morrison, A. D., \& Shapiro, J. D. (2011). Corporate governance and banks: What have we learned from the financial crisis?

Molyneux, P., \& Thornton, J. (1992). Determinants of European bank profitability: A note. Journal of banking \& Finance, 16(6), 1173-1178.

Molyneux, P., \& Thornton, J. (1992). Determinants of European bank profitability: A note. Journal of banking \& Finance, 16(6), 1173-1178.

Oshinsky, R., \& Olin, V. (2005). Troubled Banks: Why Don't They All Fail?

Pasiouras, F., \&Kosmidou, K. (2007).Factors influencing the profitability of domestic and foreign commercial banks in the European Union.Research in International Business and Finance, 21(2), 222237.

Kouser, R., Mahmood, Z., Abbas, U., (2016). Impact of Net Stable Funding Ratio Regulations on Net Interest Margin: A Multi-Country Comparative Analysis. Journal of Accounting and Finance in Emerging Economies, 2 (2) 93-104

Kouser, R., Aamir, M., Azeem, M., \&Mehwish H. (2011), CAMEL analysis for Islamic and Conventional Banks: A comparative Study in Pakistan. Finance and Economic Review (FER), Vol: 1(10), pp. 55-64.

Kouser, R., \& Saba, I. (2012).Gauging the Financial Performance of Banking Sector using CAMEL Model: Comparison of Conventional, Mixed and Pure Islamic Banks in Pakistan. International research journal of finance and economics (IRJFE) Issue (82), pp. 67-88.

Saba, I., Kibriya, R. and Kouser, R. (2015). Antecedents of Financial Performance of Banking Sector: Panel Analysis of Islamic, Conventional and Mix Banks in Pakistan. Journal of Accounting and Journal of Accounting and Finance in Emerging Economies Vol. I, No 1, June 2015 10 Finance in Emerging Economies, 1 (1) 9-30

Saba, I., Kouser, R \&Azeem, M. (2012) Determinants of Non-Performing Loans: Case of US Banking Sector. The Romanaian Economic Journal Issue (44), pp. 141-152

Schwerter, S. (2011).Basel III's ability to mitigate systemic risk.Journal of financial regulation and compliance, 19(4), 337-354.

Thomson, J. B. (1991). Predicting bank failures in the 1980s.Economic Review-Federal Reserve Bank of Cleveland, 27(1), 9.

Vazquez, F., \& Federico, P. (2015). Bank funding structures and risk: Evidence from the global financial crisis. Journal of Banking \& Finance, 61, 1-14.

Vazquez, F., \& Federico, P. (2015). Bank funding structures and risk: Evidence from the global financial crisis. Journal of Banking \& Finance, 61, 1-14.

Wheelock, D. C., \& Wilson, P. W. (2000). Why do banks disappear? The determinants of US bank failures and acquisitions. Review of Economics and Statistics, 82(1), 127-138.

Cole, R. A., \& White, L. J. (2012). Déjà vu all over again: The causes of US commercial bank failures this time around. Journal of Financial Services Research, 42(1-2), 5-29. 
